International Research Journal of Public Health
(ISSN:2573-380X)

\title{
Diabetes Mellitus: General aspects
}

Francisco Henrique da Silva ${ }^{1}$, Matheus Alves Siqueira de Assunção ${ }^{2}$, Alamisne Gomes da Silva ${ }^{3}$, Hellencléia Pereira Cunha ${ }^{3}$, Adriana Maria Costa Marques da Silva ${ }^{3}$, Aline Fernanda Carneiro Cardoso ${ }^{3}$, Fálba Bernadete Ramos dos Anjos ${ }^{2}$

${ }^{1}$ Department of Biochemistry, Federal University of Pernambuco, Recife, Pernambuco, Brazil ${ }^{2}$ Department of Histology and Embryology, Federal University of Pernambuco, Recife, Pernambuco, Brazil

${ }^{3}$ Pharmaceutical Federal University of Pernambuco, Recife, Pernambuco, Brazil

\section{ABSTRACT}

Knowing Diabetes Mellitus, as well as its main characteristics is a means of prevention. From this perspective, this chapter aims to analyze the main characteristics about Diabetes Mellitus, taking as an approach the general aspects that involve epidemiology, costs, correlation with arterial hypertension, in addition to Gestational Diabetes.

Keywords: Classification, Epidemiology, Gestational Diabetes
*Correspondence to Author:

Francisco Henrique da Silva

Department of Biochemistry, Federal University of Pernambuco, Recife, Pernambuco, Brazil

How to cite this article:

Francisco Henrique da Silva, Matheus Alves Siqueira de Assunção, Alamisne Gomes da Silva, Hellencléia Pereira Cunha, Adriana Maria Costa Marques da Silva, Aline Fernanda Carneiro Cardoso, Fálba Bernadete Ramos dos Anjos. Diabetes Mellitus: General aspects. International Research Journal of Public Health, 2020; 4:45.

\section{eScîPub}

eSciPub LLC, Houston, TX USA.

Website: https://escipub.com/ 


\section{Introduction}

The Diabetes Mellitus (DM) can be defined as a metabolic disorder of varying etiologies resulting from a deficiency in insulin secretion by beta cells $(\beta)$ and peripheral resistance to insulin action or chronic effects resulting from chronic hyperglycemia ${ }^{1}$, accompanied by disturbances in the metabolism of carbohydrates, proteins and fats, characterized by damage or failure of organs, especially kidneys, nerves, heart and blood vessels ${ }^{2}$.

\section{Classification}

The American Diabetes Association - $\mathrm{ADA}^{3}$ classifies diabetes into four categories, characterized by their etiological and pathophysiologi$\mathrm{cal}^{4}$ aspects, this classification being:

I - Type 1 diabetes mellitus

II- Type 2 diabetes mellitus

III- Gestational diabetes mellitus

IV-Other specific types of diabetes

The most common is type 2 diabetes mellitus, which occurs when the body becomes insulin resistant or not produces enough of this molecule. The Type 1 of diabetes mellitus is a chronic condition in which the pancreas produces little or no insulin on its own ${ }^{5}$. The distinction between the two types has historically been based on the age of onset, the degree of loss of $\beta$ cell function, the degree of insulin resistance, the presence of autoantibodies associated with diabetes and the need for insulin treatment for survival ${ }^{6}$.

\section{Epidemiology and costs}

The treatment of patients with diabetes mellitus (DM) presents many challenges to caregivers and represents a large proportion of health spending worldwide ${ }^{7}$. In Brazil, between 2006 and 2016, there was a $60 \%$ increase in the diagnosis of diabetes and its cost is expected to double by 2030, reaching US $\$ 97$ billion, in more conservatives numbers, or up to US $\$ 123$ billion, in the worst scenario ${ }^{8}$.

DM is one of the most serious health problems today, both in terms of the number of people affected, disabilities, premature mortality, and costs involved in its control and treatment of its complications ${ }^{9}$.

According to the WHO, it is estimated that there are 415 million adults living with diabetes in 2015 and this number increases to 642 million in $2040^{10}$, where in Brazil it affects $6.9 \%$ of the population, representing more than 13 million people, according to data from the Brazilian Diabetes Society ${ }^{11}$. Among chronic non-communicable diseases, type 2 diabetes mellitus is considered a problem, since it represents about $90 \%$ of all cases of the disease ${ }^{12}$.

In addition, The International Diabetes Federation (IDF) ${ }^{13}$ says about 1.1 million children and adolescents between 14 and 19 years of age has DM1. This disease is responsible for about $5 \%$ of all deaths worldwide, where $80 \%$ of diabetics are in low or medium development countries, according to the World Health Organization.

As a way to increase awareness about the disease and the care related to its prevention and treatment, the blue circle (Figure 1), to the agreement with IDF ${ }^{13}$, has become the official symbol of diabetes.

\section{Diabetes and hypertension}

Food is one of the factors that encompass the control and prevention of

systemic arterial hypertension (SAH) and diabetes mellitus (DM) ${ }^{14}$, where the costs in the Brazilian Health System of hypertension and diabetes, also associated with obesity, reached $\mathrm{R} \$$ 3.45 billion in 2018, where $59 \%$ were related to treatment of hypertension, $30 \%$ to diabetes and $11 \%$ to obesity ${ }^{15}$. In addition, arterial hypertension and diabetes mellitus represent two of the main risk factors for the occurrence of cardiovascular diseases ${ }^{16}$.

\section{Diabetes and pregnancy: risks}

Gestational diabetes mellitus (GDM) is a pathology of carbohydrate intolerance of varying degree and severity, diagnosed for the first time in pregnancy. It is a common pathology, with several means of prevention and treatment ${ }^{17}$. The prevalence of GDM varies in different parts of 
the world, according to different racial and ethnic groups ${ }^{18}$, being considered a Public Health problem. If not controlled it can cause complications for the mother and the fetus, where the fetal im- pairment is directly linked to the maternal hyperglycemic state, interfering with fetal homeostasis and causing macrosomia, fetal prematurity or even malformations ${ }^{19}$.

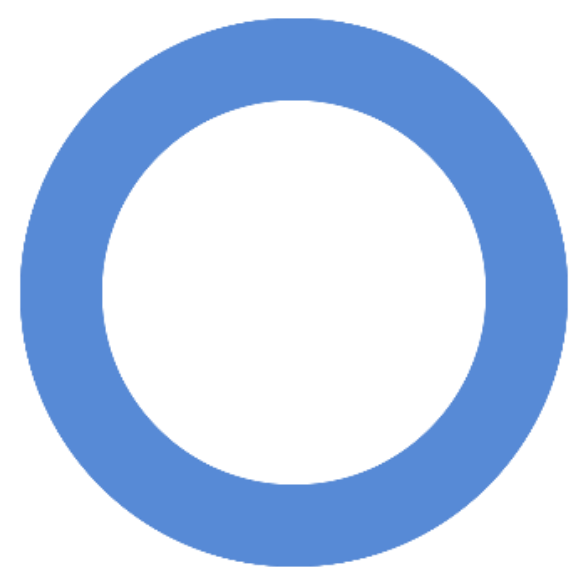

Figure 1. Universal symbol of diabetes Source: Author

\section{Complications}

The complications of GDM are many, both for the mother and baby, being them for neonatal hypoglycemia and newborns large for gestational age, in addition to prematurity, jaundice requiring phototherapy, respiratory distress syndrome, sepsis, greater risk of developing obesity, systemic arterial hypertension, metabolic syndrome and diabetes Mellitus in adulthood; macrosomy, hyperbilirubinemia, caudal regression syndrome, polycythemia, hypocalcemia, intrauterine growth retardation, tocotrauma and shoulder distortion ${ }^{20}$.

\section{Gestational process}

Pregnancy is a biological process that has social, economic, emotional and psychological repercussions, so it is important to know the socioeconomic conditions of pregnant women with diabetes for a better diagnosis and effective treatment ${ }^{21}$. Due to the importance of the topic, you should study the characteristics of managers with diabetes, establishing a wide discussion about the use of oral hypoglycemic agents in the life stage and their possible teratogenic poten$\mathrm{tial}^{22}$.
As the insulin needs increase and more than half of pregnant women with DM1 present excessive weight gain ${ }^{23}$, where the predisposition for this pathological condition involves characteristics such as age equal to or greater than 35 years, overweight or obesity, central deposition of pregestational body fat, gain excessive in the current pregnancy, hypertension or pre-eclampsia in the current pregnancy, family history of firstdegree diabetes, obstetric history of macrosomia, fetal or neonatal death, malformations, political ovary syndrome and maternal height less than 1.5 meters ${ }^{24}$.

The management of diabetes must be carried out within a hierarchical health system, being the base or the primary level. Women with gestational diabetes mellitus should be referred to Secondary Care Centers. As carriers of the prepregnancy diagnosis, they should be attended to in tertiary care centers by a multidisciplinary team ${ }^{25}$.

For those monitored in Secondary or Tertiary Care Centers or follow-up it will be through Primary Care Teams, the greater control and adherence to the procedures recommended at the most complex levels ${ }^{26}$. 


\section{Conclusions}

Understanding the main resources related to diabetes mellitus provides an effective therapeutic approach against the main clinical manifestations of the disease, in addition to promoting disease prevention in therapeutic situations such as pregnancy.

\section{References}

1. de Brito ANM, Macedo JL, de Lima Carvalho S, de Oliveira JVF, Brito FNM, Pinheiro A. et al. Effectiveness of diet therapy for patients with diabetes mellitus. Research, Society and Development. 2020: 9(1), 114911728.

2. Valença TVR, Sangiovo A, Pereira F, Vincensi C, Lissarassa YPS, Zimmermann CE et al. Obesidade, diabetes e hipertensão associados a dislipidemia e dano hepático. Revista saúde integrada. 2018: V. 11(22), 2-18.

3. ADA 2015B American Diabetes Association et al. Classificação e diagnóstico de diabetes. Seção 2. Padrões de Assistência Médica em Diabetes-2015. Diabetes Care. 2015: v. 38, n. 1, p. S8-S16.

4. Sanzana MG, Durruty P. Otros tipos específicos de diabetes mellitus. Revista Médica Clínica Las Condes. 2016: 27(2), 160-170.

5. World Health Organization. Classification of diabetes mellitus. 2019.

6. Leslie RD, Palmer J, Schloot NC, Lernmark A. Diabetes at the crossroads: relevance of disease classification to pathophysiology and treatment. Diabetologia. 2016:. 59(1), 13-20.

7. Dean PG, Kukla A, Stegall MD, Kudva YC. Transplante de pancreas. Bmj. 2017: 357: j1321

8. Sociedade Brasileira de Análises Clínicas. Qual a situação da diabetes no Brasil? [Internet]. [place unknown]; 2018 Nov 26 [cited 2020 Apr 4]. Available

from:

http://www.sbac.org.br/blog/2018/11/26/qual-asituacao-da-diabetes-no-brasil/.

9. González CRM. Intervenção educativa em diabéticos na unidade de saúde da família Walda Moura III, Eunápolis, Bahia. 2017.

10. World Health Organization. Global report on diabetes, 2016. Disponível em:< http://apps.who.int/iris/bitstream/10665/204871/1 /9789241565257_eng.pdf>

11. Sociedade Brasileira DE Diabetes. $O$ que é diabetes? Disponível em:<http://www.diabetes.org.br/publico/diabetes loque-e-diabetes $>$.
12. Costa AF, Flor LS, Campos MR, Oliveira AFD, Costa MDFDS, Silva RSD et al. Carga do diabetes mellitus tipo 2 no Brasil. Cadernos de Saúde Pública. 2017:33, e00197915.

13. Federação Internacional de Diabetes IDAT. Atlas de Diabetes da IDF, 8 $8^{\text {a }}$ ed. Bruxelas, Bélgica: Federação Internacional de Diabetes, 2017

14. Destri K, Zanini RDV, Assunção MCF. Prevalência de consumo alimentar entre hipertensos e diabéticos na cidade de Nova Boa Vista, Rio Grande do Sul, Brasil, 2013. Epidemiologia e Serviços de Saúde. 2017: 26, 857-868.

15. Nilson EAF, Andrade RDCS, Brito DAD, Oliveira MLD. Custos atribuíveis a obesidade, hipertensão e diabetes no Sistema Único de Saúde, Brasil, 2018. Revista Panamericana de Salud Pública.2020: 44, 32.

16. Neto EMN. Doenças crônicas (diabetes mellitus e hipertensão arterial) entre trabalhadores da saúde na bahia: análise de relação com hábitos de vida e estressores ocupacionais. Anais Seminário de Iniciação Científica. 2017: 21.

17. Kunzendorff BA, Nicoli BM, Luz FA, Martins KG, Mendes AA. A influência da diabetes mellitus no período gestacional como fator de risco. Anais do Seminário Científico do UNIFACIG. 2018: 3.

18. Rodrigues IM, Abreu B, Figueiredo A, Amaral N, Pereira N, Dias E, Veríssimo C. Impacto da etnia/raça na diabetes gestacional. Acta Obstétrica e Ginecológica Portuguesa. 2019: 13(2), $72-80$.

19. Mayer GE. Diabetes mellitus gestacional: o papel do exercício físico como tratamento não farmacológico. 2017.

20. Freires JD, da Costa Azevedo OO, de Souza OKS, de Lima MN, Lima DV, Porfirio PA et al. Diabetes Gestacional E Complicações Fetais/Neonatais. International Journal of Nutrology. 2018, 11(S 01), Trab295.

21. Silva R. Avaliação socioeconômica, de saúde e antropométrica de mulheres com diabetes mellitus gestacional e os seus recémnascidos (Bachelor's thesis, Universidade Federal do Rio Grande do Norte). 2018.

22. Quevedo MP, Lopes CMC, Lefèvre F. Os significados da maternidade para mulheres cardiopatas e diabéticas com gravidez de risco. Journal of Human Growth and Development. 2006: 16(1), 12-21.

23. Teixeira CPA. Diabetes Mellitus tipo 1 e Gravidez. 2019. 
24. Guerra JVV, Alves VH, Sobrinho COV, Pereira AV, Rodrigues DP. Diabetes gestacional e assistência pré-natal de alto risco em um hospital universitário [Gestational diabetes and high-risk prenatal care in a university hospital] [Diabetes gestacional y atención prenatal de alto riesgo en un hospital universitario]. Enfermagem Obstétrica. 2018: 5, e105.

25. Rodrigues DB. Referência e contrarreferência no cuidado da gestante de alto risco em rede de atenção à saúde sob a ótica da complexidade.2018.

26. Brasil. Ministério da Saúde. Secretaria de Atenção à Saúde. Departamento de Atenção Básica. Estratégias para o cuidado da pessoa com doença crônica: diabetes mellitus / Ministério da Saúde, Secretaria de Atenção à Saúde, Departamento de Atenção Básica. - Brasília: Ministério da Saúde, 2013. 
- Title: International Research Journal of Public Health

- ISSN: 2573-380X

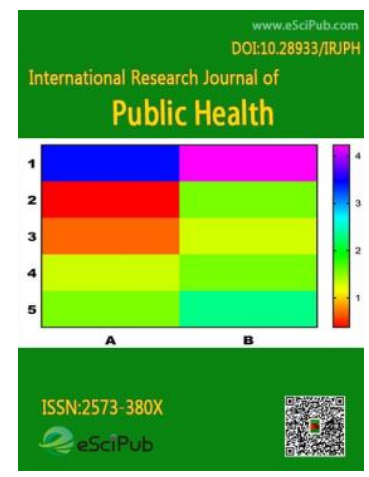

- DOI: $10.28933 / \mathrm{IRJPH}$

- IF: 1.36 (citefactor)

- Email: IRJPH@escipub.com

- TEL: +1-281-656-1158

\title{
About the journal
}

The journal is hosted by eSciPub LLC. Our aim is to provide a platform that encourages publication of the most recent research and reviews for authors from all countries.

\begin{abstract}
About the publisher
eSciPub LLC is a publisher to support Open Access initiative located in Houston, Texas, USA. It is a member of the largest community of professional publishers in the United States: the Independent Book Publishers Association. It hosts more than 100 Open Access journals in Medicine, Business \& Economics, Agriculture, Biological Sciences, Chemistry, Education, Physical Sciences, Sociology, and Engineering and Technology.
\end{abstract}

\section{Rapid Response Team}

Please feel free to contact our rapid response team if you have any questions. Our customer representative will answer your questions shortly.

\section{BY 4.0}

This work and its PDF file(s) are licensed under under a Creative Commons Attribution 4.0 International License.

\section{Terms of Use/Privacy Policy/ Disclaimer/ Other Policies:}

You agree that by using our site, you have read, understood, and agreed to be bound by all of our terms of use/privacy policy/ disclaimer/ other policies (click here for details). This site cannot and does not contain professional advice. The information on this site is provided for general informational and educational purposes only and is not a substitute for professional advice. Accordingly, before taking any actions based upon such information, we encourage you to consult with the appropriate professionals. We do not provide any kind of professional advice. The use or reliance of any information contained on this site or our mobile application is solely at your own risk. Under no circumstance shall we have any liability to you for any loss or damage of any kind incurred as a result of the use of the site or our mobile application or reliance on any information provided on the site and our mobile application. We may publish articles without peer-review. Published articles of authors are open access. Authors hold the copyright and retain publishing rights without restrictions. Authors are solely responsible for their articles published in our journals. Publication of any information in authors' articles does not constitute an endorsement by us. We make no representation or warranty of any kind, express or implied, regarding the accuracy, adequacy, validity, reliability, availability or completeness of any information that authors provided. more..... 